\title{
De Novo Formal Synthesis of (-)-Apicularen A via an Iterative Asymmetric Hydration Sequence
}

\author{
Miaosheng Li and George A. O'Doherty \\ Department of Chemistry, West Virginia University, Morgantown, WV 26506
}

\section{Abstract}<smiles>C=C/C=C\C=C/C(=O)N/C=C/CC(O)CC1C[C@@H](O)C[C@H](Cc2cccc(O)c2C(=O)O)O1</smiles>

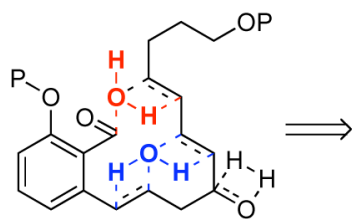<smiles>CCCCOCCC/C=C/C=C/C(=O)OCC</smiles>

(-)-Apicularen A

A de novo approach to the formal total synthesis of the macrolide natural product (-)-apicularen A has been achieved in 18 steps from achiral starting materials.Both the absolute and relative stereochemistry of apicularen A were introduced by a Sharpless asymmetric dihydroxylation, a $\pi$ allyl-palladium catalyzed reduction, a stereoselective reduction and a base promoted transannulation to install the $C-9$ stereocenter.

Since its isolation and structural determination by Jansen and co-workers, ${ }^{1}$ apicularen A has attracted significant interest due to its extremely potent antitumor activity, apicularen A showed remarkable cytotoxicities against nine human cancer lines at quite low concentration $\left(\mathrm{IC}_{50} \sim\right.$ 0.1-3 ng/mL). This activity persisted even with the multi-drug resistant line, $\mathrm{KB}-\mathrm{VI}\left(\mathrm{IC}_{50} \sim\right.$ $0.4 \mathrm{ng} / \mathrm{mL}) .{ }^{1 \mathrm{~b}}$ Recently, the mode of action for the apicularens was demonstrated to occur via the selective inhibition of the mammalian VATPases, ${ }^{2}$ which are responsible for regulating the intracellular $\mathrm{pH}$. Interestingly, while apicularen $\mathrm{A}$ and $\mathrm{B}$ were equipotent inhibitors of VATPases, apicularen $\mathrm{A}$ is $\sim 100$ times more toxic to cancer cells. ${ }^{1 \mathrm{~b}}$ This switch in activity controlled by glycosylation has peaked our interest in the synthesis of both apicularen A and $\mathrm{B}$, as well as other glycosylated potential prodrugs.

In addition to its fascinating biological activities, the structural novelty of apicularen A has also attracted the attention of the synthetic community. To date several total syntheses of apicularen A have been completed, ${ }^{3}$ along with several formal total syntheses and various efforts to the unique bicyclic ring system. ${ }^{4}$ While all of the previous syntheses of the apicularen A derived their asymmetry by a resolution or from the chiral pool, we were interested in a de novo asymmetric approach that would use asymmetric catalysis to install the four stereocenters in apicularen A from achiral starting materials. Herein we describe our successful efforts to implement this strategy for the de novo formal total synthesis of apicularen A.

Retrosynthetically, we envisioned apicularen A (1) and apicularen B (2) as being derived from the known macrolide 3 and the amide side chain $\mathbf{4}$, which have been successfully used by Maier

George.ODoherty@mail.wvu.edu.

Supporting Information Available: Complete experimental procedures and spectral data for all new compounds can be found in the Supporting Information. This material is available free of charge via the Internet at http://pubs.acs.org. 
for the synthesis of $\mathbf{1}$ (Scheme 1). ${ }^{5}$ In our strategy (Scheme 2), the macrolide 3 could be derived from macrolactone $\mathbf{5}$, which in turn could be obtained by cross metathesis of styrene $\mathbf{6}$ and alkene $\mathbf{7}$. The homoallylic alcohol stereochemistry in the differentially protected tetraol 7 was planned to be introduced by the diastereoselective introduction of an allyl-group to the benzylidene-protected triol 8. $^{6}$ Previously we have been successful at preparing protected 3,5dihydroxy esters from 2,4-dienoates. 6,7 Thus, we envisioned using this 4-step asymmetric bishydration protocol for the preparation of benzylidene acetal $\mathbf{8}$ from dienoate $\mathbf{9}$.

To access of useful quantities of dienoate $\mathbf{9}$, an efficient 5-step approach was developed (Scheme 3). The route featured the KAPA promoted alkyne zipper reaction ${ }^{8}$ and the $\mathrm{Ph}_{3} \mathrm{P}$ promoted ynoate to dienoate isomerization, developed by Trost. ${ }^{9}$ Treatment of the lithium acetylide of $\mathbf{1 0}$ with paraformaldehyde gave good yield (87\%) of a propargylic alcohol, which when exposed to the KAPA reagent readily isomerized to the terminal heptynol $11(79 \%)$. The primary alcohol in $\mathbf{1 1}$ was easily protected as a benzyl ether $(\mathrm{KH} / \mathrm{BnBr}, 92 \%)$ and the terminal alkyne was carboxylated ( $n$-BuLi/ClCO $\left.{ }_{2} \mathrm{Et}, 93 \%\right)$ to give ynoate 12. Exposure of alkynoate 12 to the Rychnovsky variant of the Trost isomerization $\left(\mathrm{Ph}_{3} \mathrm{P} / \mathrm{PhOH}\right)$ cleanly gave dienoate $\mathbf{9}$ in excellent yield (95\%) and near perfect double bond stereoselectivity.

We next turned to our 3-step asymmetric hydration protocol (dihydroxylation, carbonate formation and palladium catalyzed reduction) to convert dienoate $\mathbf{9}$ into $\delta$-hydroxyenoate 14. In practice, dienoate 9 was dihydroxylated under the Sharpless conditions to give diol, which was cyclized into carbonate $\mathbf{1 3}$ in good overall yield (78\%). Exposure of carbonate $\mathbf{1 3}$ to the palladium $(0)$ catalyzed reduction conditions $\left(\mathrm{HCO}_{2} \mathrm{H} / \mathrm{Et}_{3} \mathrm{~N}\right)$ provided $\delta$-hydroxy enoate $\mathbf{1 4}$ in good yield (90\%). With the initial chiral center introduced in $\delta$-hydroxy enoate 14, the remaining double bond was diastereoselectively hydrated and protected to form the benzylidene acetal 8 using Evans' procedure (PhCHO/t-BuOK, 59\%). ${ }^{10}$ The ester 8 was then converted into Weinreb amide $16(\mathrm{ClMgN}(\mathrm{OMe}) \mathrm{Me})$ in $89 \%$ yield (Scheme 3$).{ }^{11}$

Exposure of Weinreb amide $\mathbf{1 6}$ to allylmagnesium chloride cleanly formed the ketone $\mathbf{1 7}$ in $86 \%$ yield (Scheme 4). Reduction of the ketone under various conditions resulted in different ratios of diastereomers 18 and 19. Our optimized conditions used L-selectride, which produced homoallylic alcohols 18 and 19 in a ratio of 7:1. The two diastereomers 18 and 19 were separable by careful chromatography. The undesired isomer 19 can be recycled by a DessMartin oxidation back to ketone $\mathbf{1 7}$ (94\%). Alternatively, treatment of aldehyde 20, which was formed by Dibal-H reduction of ester $\mathbf{8}(92 \%)$, with the Leighton reagent formed the desired homoallylic alcohol 18 in high diastereoselectivity (97:3) and high yield (88\%). ${ }^{12}$ Finally, the alcohol in $\mathbf{1 8}$ was protected as benzyl ether to provide the cross metathesis precursor $\mathbf{7}$.

We next looked at the synthesis of styrene fragment 6 (Scheme 5). Selective monomethylation ${ }^{13}$ of commercially available salicylic acid 21 (DBU/MeI, 82\%) was followed by treatment of the remaining phenol group with $\mathrm{Tf}_{2} \mathrm{O}$ to give triflate $\mathbf{2 2}(89 \%)$. The Molander ${ }^{14}$ trifluoroborate variant of the Suzuki-Miyaura ${ }^{15}$ coupling was then used to convert the triflate $\mathbf{2 2}$ to the styrene $\mathbf{6}(91 \%)$.

The merging of the two alkenes $\mathbf{6}$ and $\mathbf{7}$ via an olefin cross metathesis reaction was then investigated. Treatment of 6 ( 2 equiv) and 7 with the second generation Grubbs reagent (5\% Grubbs II) ${ }^{16}$ provided the cross metathesis product 23 in good yield (86\%) and high transstereoselectivity (Scheme 5).

In preparation for the macrolactone assembly (Scheme 6), the benzylidene protection group in 23 was removed with mildly acidic conditions $\left(4: 1 \mathrm{AcOH} / \mathrm{H}_{2} \mathrm{O}, 80{ }^{\circ} \mathrm{C}\right)$ to form diol $\mathbf{2 4}(82 \%)$. 17 Then the methyl ester $\mathbf{2 4}$ was hydrolyzed with $\mathrm{LiOH} .{ }^{18}$ Applying a modified Yamaguchi lactonization ${ }^{19}$ procedure to the seco-acid $\mathbf{2 5}$ selectively produced the 12-member macrolactone $6(67 \%)$ over the 10 -membered ring. With the macrolactone established we next 
looked for an alternative to the Maier transannular etherification. ${ }^{3 \mathrm{~d}}$ After numerous fruitless investigations, including $\mathrm{Au}(\mathrm{I})^{20}$, and $\mathrm{Pt}(\mathrm{II})^{21}$ catalysts, we eventually found that the tetrahydropyran could be formed under basic ( $t$-BuOK, 1 equiv) conditions. Significantly, only one diastereomer was formed under these conditions and in good yield $(83 \%){ }^{22}$ The desired target macrolide 3 was identical physically (mp, optical rotation) and spectroscopically ${ }^{1} \mathrm{H}$ NMR, ${ }^{13} \mathrm{C}$ NMR, IR and MS) to the material previously reported by Maier. ${ }^{3 \mathrm{~d}}$

In conclusion, a short formal de novo asymmetric synthesis of apicularen A has been developed. This highly enantio- and diastereocontrolled route illustrates the utility of our dienoate asymmetric hydration strategy for natural product synthesis. In addition, this approach features a cross metathesis reaction, a Yamaguchi lactonization and a base mediated transannular etherification. Further application of this approach to the synthesis of other members of this class of compounds and biological testing are ongoing.

\section{Supplementary Material}

Refer to Web version on PubMed Central for supplementary material.

\section{Acknowledgments}

We are grateful to Dr. Joseph Dougherty (WVU) for initial exploratory work and to the NIH (GM63150) and NSF (CHE-0415469) for the support of our research program and NSF-EPSCoR (0314742) for a $600 \mathrm{MHz}$ NMR and an LTQ-FT Mass Spectrometer at WVU.

\section{References}

1 (a). Kunze B, Jansen R, Sasse F, Höfle G, Reichenbach H. J. Antibiot 1998;51:1075-1080. [PubMed: 10048565] (b) Jansen R, Kunze B, Reichenbach H, Höfle G. Eur. J. Org. Chem 2000:913-919.

2 (a). Boyd MR, Farina C, Belfiore P, Gagliardi S, Kim JW, Hayakawa Y, Beutler JA, McKee TC, Bowman BJ, Bowman EJ. J. Pharmacol. Exp. Ther 2001;297:114-120. [PubMed: 11259534] (b) Huss M, Sasse F, Kunze B, Jansen R, Steinmetz H, Ingenhorst G, Zeeck A, Wieczorek H. BMC Biochem 2005;6:13. [PubMed: 16080788]

3 (a). Bhattacharjee A, Seguil OR, De Brabander JK. Tetrahedron Lett 2001;42:1217-1220. (b) Nicolaou KC, Kim DW, Baati R. Angew. Chem. Int. Ed 2002;41:3701-3704. (c) Su Q, Panek JS. J. Am. Chem. Soc 2004;126:2425-2430. [PubMed: 14982450] (d) Petri AF, Bayer A, Maier ME. Angew. Chem. Int. Ed 2004;43:5821-5823.

4 (a). Lewis A, Stefanuti I, Swain SA, Smith SA, Taylor RJK. Tetrahedron Lett 2001;42:5549-5552. (b) Lewis A, Stefanuti I, Swain SA, Smith SA, Taylor RJK. Org. Biomol. Chem 2003;1:104-116. [PubMed: 12929396] (c) Graetz BR, Rychnovsky SD. Org. Lett 2003;5:3357-3360. [PubMed: 12943426] (d) Kühnert S, Maier ME. Org. Lett 2002;4:643-646. [PubMed: 11843612] (e) Hilli F, White JM, Rizzacasa MA. Tetrahedron Lett 2002;43:8507-8510. (f) Hilli F, White JM, Rizzacasa MA. Org. Lett 2004;6:1289-1292. [PubMed: 15070319]

5. While Maier's endgame seemed ideal for our purpose, his use of a stochiometric amount $\left(\mathrm{CF}_{3} \mathrm{CO}_{2}\right)_{2} \mathrm{Hg}$ to set the trans-annular ether bridge in macrolide 3 (see ref $3 \mathrm{~d}$ ) was viewed as needing to be replaced with an environmentally more benign yet equally stereoselective process.

6. Hunter TJ, O’Doherty GA. Org. Lett 2001;3:2777-2780. [PubMed: 11506632] (b) Tosaki SY, Nemoto T, Ohshima T, Shibasaki M. Org. Lett 2003;5:495-498. [PubMed: 12583752] (c) Smith CM, O’Doherty GA. Org. Lett 2003;5:1959-1962. [PubMed: 12762696]

7 (a). Hunter TJ, O'Doherty GA. Org. Lett 2001;3:1049-1052. [PubMed: 11277792] (b) Li M, O’Doherty GA. Org. Lett 2006;8:3987-3990. [PubMed: 16928055]

8 (a). Brown CA, Yamashita A. J. Am. Chem. Soc 1975;97:891-892. (b) Kimmel T, Becker D. J. Org. Chem 1984;49:2494-2496.

9 (a). Rychnovsky SD, Kim J. J. Org. Chem 1994;59:2659-2660. (b) Trost B, Kazmaier U. J. Am. Chem. Soc 1992;114:7933-7935.

10. Evans DA, Gauchet-Prunet JA. J. Org. Chem 1993;58:2446-2453. 
11 (a). Nahm S, Weinreb SM. Tetrahedron Lett 1981;22:3815-3818. (b) Williams JM, Jobson RB, Yasuda N, Marchesini G, Dolling U-H, Grabowski EJ. Tetrahedron Lett 1995;36:5461-5464.

12. Previous approaches to apicularen A used the Brown AllylBIpc 2 reagent, see: refs $3 \mathrm{~b}, 3 \mathrm{c}, 4 \mathrm{~b}$ and $4 \mathrm{f}$. We have found that the Leighton reagent works equally well in terms of stereochemical outcome and allows for a significantly simpler product isolation procedure, see: Kubota K, Leighton J. Angew. Chem. Int. Ed 2003;42:946-948.

13. Mal D. Synth. Commun 1986;16:331-335.

14. Molander GA, Rivero MR. Org. Lett 2002;4:107-109. [PubMed: 11772102]

15. Miyaura N, Suzuki A. Chem. Rev 1995;95:2457-2483.

16. Scholl M, Ding S, Lee CW, Grubbs RH. Org. Lett 1999;1:953-956. [PubMed: 10823227]

17. Efforts to lactonize diol $\mathbf{2 4}$ under various basic conditions ( $\mathrm{NaH}, \mathrm{KH}$, or $t$-BuOK) caused either decomposition of the starting material or no reaction.

18. Petri AF, Kuhnert SM, Scheufler F, Maier ME. Synthesis 2003;6:940-955.

19 (a). Inanaga J, Hirata K, Saeki H, Katsuki T, Yamaguchi M. Bull. Chem. Soc. Jpn 1979;52:1989_ 1993. (b) Mulzer J, Mareski PA, Buschmann J, Luger P. Synthesis 1992;1:215-234.

20. Yang C-G, He C. J. Am. Chem. Soc 2005;127:6966-6967. [PubMed: 15884936]

21. Qian H, Han X, Widenhoefer RA. J. Am. Chem. Soc 2004;126:9536-9537. [PubMed: 15291546]

22. The high diastereoselectivity associated with this transannular cyclization ( 5 to 3 ) has precedent in the work of Rizzacasa, see: refs $4 \mathrm{e}$ and $4 \mathrm{f}$. Our results suggest the possibility of an olefin migration preceding cyclization, in Rizzacasa model study, instead of the proposed 6-endo-dig cyclization, see: ref $4 \mathrm{e}$. 


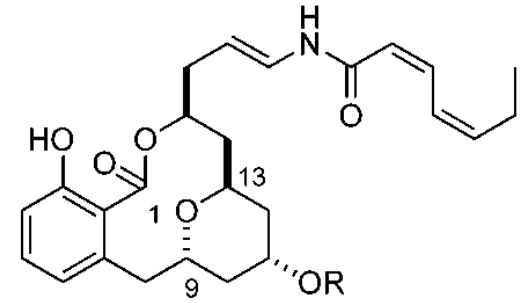

$(-)$-Apicularen $A, 1, R=H$

(-)-Apicularen $\mathrm{B}, 2, \mathrm{R}=\mathrm{N}$-acetyl- $\beta$-glucosamine

\begin{tabular}{ccc}
$\begin{array}{c}\text { Gl of M1 } \\
\text { cell line } \\
\left(\mathrm{IC}_{50}\right)\end{array}$ & $\begin{array}{c}\text { V-ATPases } \\
\text { inhibition } \\
\left(\mathrm{IC}_{50}\right)\end{array}$ \\
\hline $\mathbf{1}$ & $1.4 \mathrm{nM}$ & $\sim .5 \mu \mathrm{M}$ \\
$\mathbf{2}$ & $190 \mathrm{nM}$ & $\sim .5 \mu \mathrm{M}$
\end{tabular}

Scheme 1.

Biological Activity of (-)-Apicularen A and $\mathrm{B}^{2 \mathrm{~b}}$ 


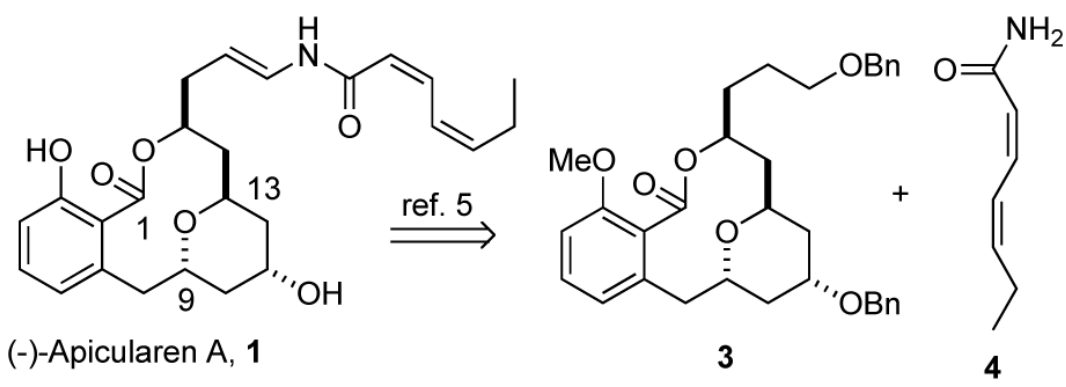

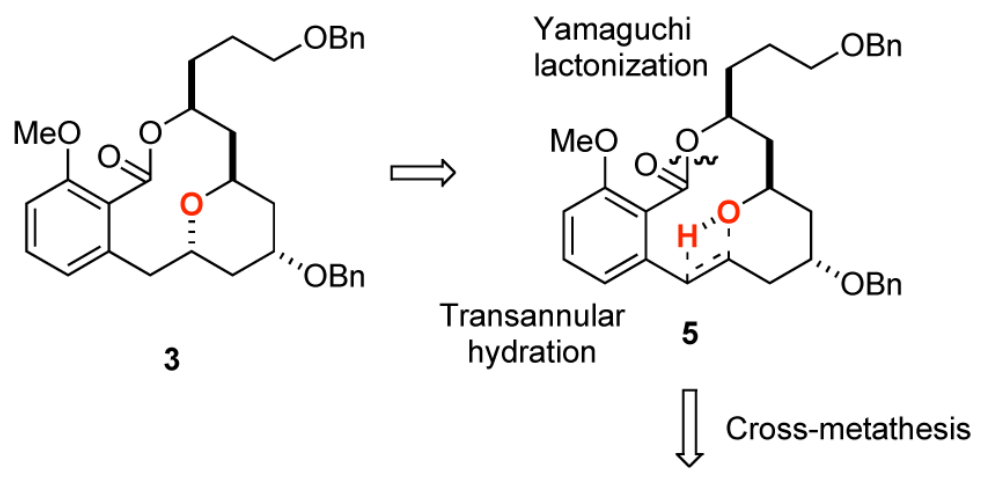<smiles>C=CCC(CC1CC(CCCOCc2ccccc2)OC(c2ccccc2)O1)OCCc1ccccc1</smiles>

6<smiles>C=CCOC(=O)CC1CC(CCCOCc2ccccc2)OC(c2ccccc2)O1</smiles>

Scheme 2.

Retrosynthesis of (-)-Apicularen A (1). 

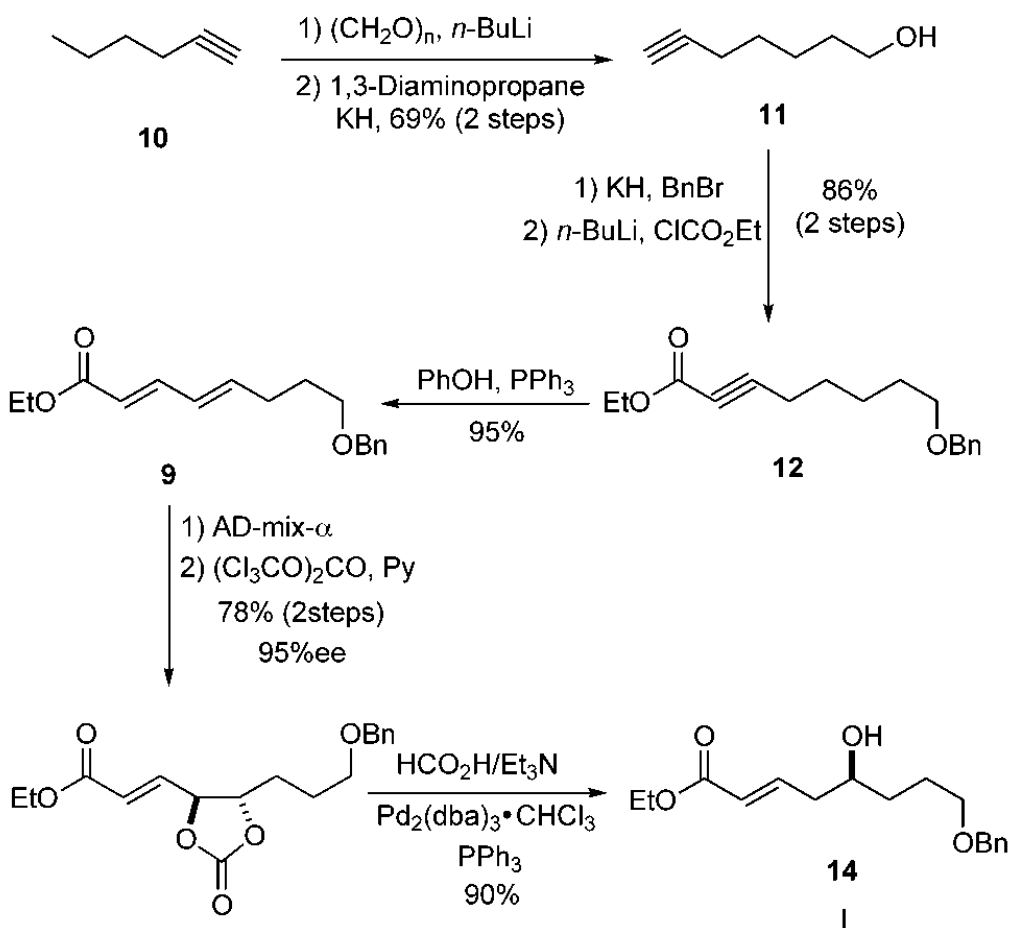

13

$\mathrm{PhCHO}, t$-BuOK $59 \%$

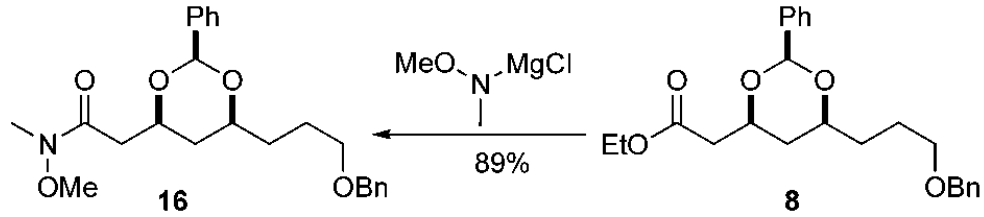

Scheme 3.

Synthesis of Dienoate 9 and Its Bis-hydration. 
<smiles>C=CCN(C)C(=O)CCCCCCC(=O)CC1CC(CC(=O)N(C)OC)OC(c2ccccc2)O1</smiles><smiles>[Y12]C1CC(C[C@@H](O)CC=C)OC(c2ccccc2)O1</smiles>
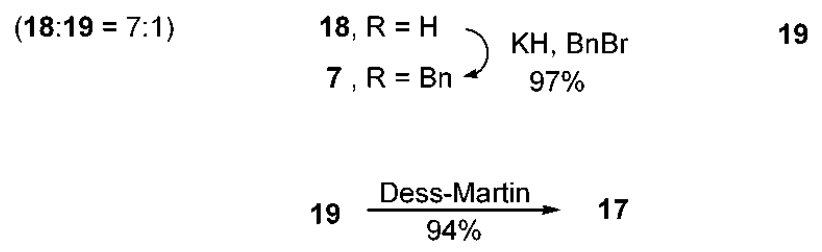<smiles>CCCCOCCCC1CC(CC(=O)OCC)OC(c2ccccc2)O1</smiles>

8

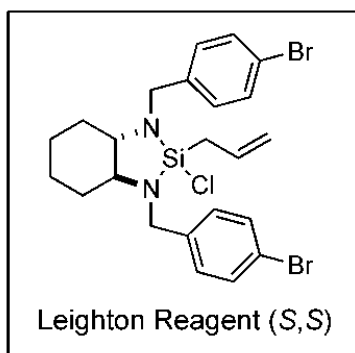

Scheme 4.

Synthesis of Intermediate 7 via Stereoselective Reduction or Asymmetric Allylation. 
<smiles>CCCCOc1cccc(OC)c1C(=O)O</smiles>

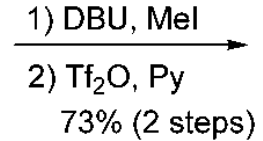
$73 \%$ (2 steps)<smiles>COC(=O)c1c(OC)cccc1OC</smiles><smiles>C=Cc1cccc(OC)c1C(=O)OC</smiles><smiles>COC(=O)c1c(/C=C/CC(Cc2ccccc2)CC2CC(CCCOCc3ccccc3)OC(c3ccccc3)O2)cccc1OC</smiles>

Scheme 5.

Synthesis of Salicylate $\mathbf{2 3}$ via Cross-Metathesis Reaction. 


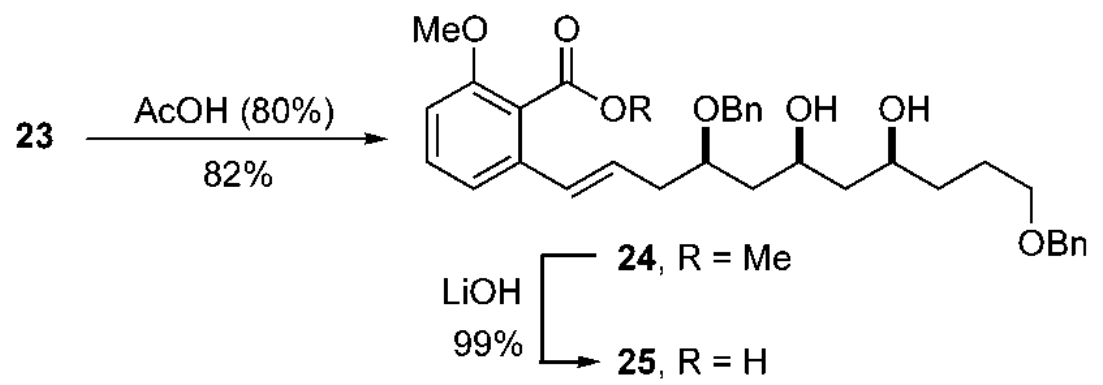

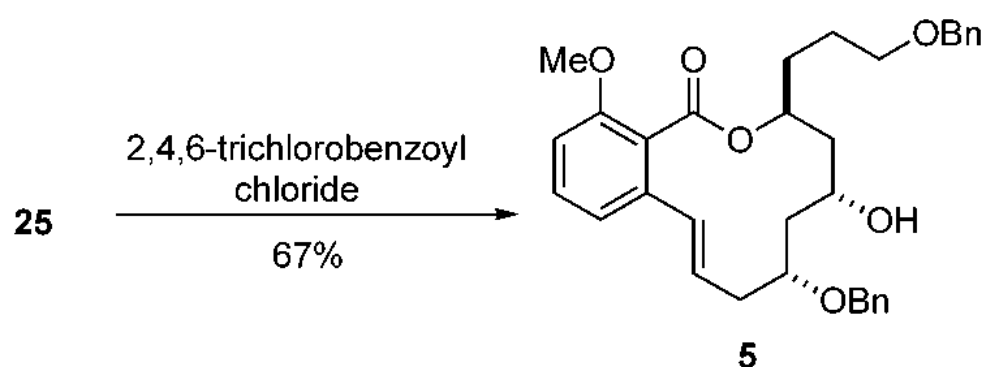<smiles>COc1cccc(C[C@@H]2C[C@H](OCc3ccccc3)C[C@H](CC(CCCOCc3ccccc3)OC(=O)OC(C)(C)C)O2)c1C(=O)OCC(C)(C)C</smiles>

Scheme 6.

Completion of Formal Synthesis of (-)-Apicularen A. 